\title{
Simulated Fireside Corrosion of T91 in Oxy-combustion Systems with an Emphasis on Coal/Biomass
}

\section{Environments}

Gordon R. Holcomb, Casey S. Carney, Joseph Tylczak, Tomasz P. Dudziak and Nigel J. Simms

Gordon R. Holcomb (Corresponding Author), National Energy Technology Laboratory, 1450 Queen Ave SW, Albany, Oregon 97321, USA, 1-541-967-5874, Gordon.Holcomb@netl.doe.gov, ORCID 00000003-3542-5319

Casey S. Carney, AECOM and National Energy Technology Laboratory, 1450 Queen Ave SW, Albany, Oregon 97321, USA, Casey.Carney@netl.doe.gov, ORCID 0000-0002-6311-4641

Joseph Tylczak, National Energy Technology Laboratory, 1450 Queen Ave SW, Albany, Oregon 97321, USA, Joseph.Tylczak@netl.doe.gov, ORCID 0000-0002-0391-2350

Tomasz P. Dudziak, Cranfield University, Cranfield, Bedfordshire MK43 OAL, UK, tomasz.dudziak@iod.krakow.pl, ORCID 0000-0003-3901-7531

Info for footnote: Tomasz Dudziak is now at Sieć Badawcza łukasiewicz - Instytut Odlewnictwa (Lukasiewicz Research Network - Foundry Research Institute), Zakopiańska 73, 30-418, Krakow, Poland

Nigel J. Simms, Cranfield University, Cranfield, Bedfordshire MK43 OAL, UK, N.J.Simms@cranfield.ac.uk, ORCID 0000-0002-8865-9138

\begin{abstract}
Oxy-combustion is the burning of a fuel in oxygen rather than air for the ease of capture of $\mathrm{CO}_{2}$ for reuse or sequestration. Corrosion issues associated with the change in heat exchanger tube operating environment (replacement of most of the $\mathrm{N}_{2}$ with $\mathrm{CO}_{2}$ and potentially higher $\mathrm{SO}_{x}$ levels) from air- to oxycombustion, were examined. The ferritic-martensitic alloy T91 was used in accelerated fireside corrosion tests using several different gas compositions and ash deposit overcoats to simulate air-fired, oxy-fired coal, and oxy-fired co-fired coal/biomass conditions. Initial corrosion was observed after $240 \mathrm{~h}$ of exposure by examining cross-sections with retained ash. Metal section losses were determined after exposures of up to $1440 \mathrm{~h}$ at $600-700^{\circ} \mathrm{C}$. Severe corrosion was observed, and a corrosion response with respect to ash deposit chemistry was observed. Corrosion response differences with respect to gas phase chemistry were minimal. Alloy-oxide scale-ash morphologies were consistent with oxide fluxing mechanisms.
\end{abstract}

Keywords: Fireside Corrosion, Oxidation, Oxy-combustion, Co-firing, Boilers, Fluxing, T91

\section{Introduction}

Research into improved materials systems and associated manufacturing and reliability issues is a major part of initiatives to economically reduce greenhouse gas emissions (primarily $\mathrm{CO}_{2}$ ). The UK-US Memorandum of Understanding on Energy R\&D between the United Kingdom Department of Climate Change (now Department of Business, Energy and Industrial Strategy) and the United States Department of Energy has provided the opportunity for collaboration between UK and US organizations in advanced materials for power generation [1]. Under this agreement, the organizations involved collaborate and share the results of Government or self-funded projects to maximize the return and benefit for the 
participating organizations and more rapidly advance underlying mechanistic understanding and materials development. Using this framework, a task addressing boiler fireside corrosion under oxy-fuel conditions was initiated. The focus was on the effects of deposit and gas-phase chemistry on the potential corrosion mechanisms.

Oxy-combustion based power generation combusts coal in relatively pure oxygen $\left(\mathrm{O}_{2}\right)$ and re-cycled flue gases to enable the capture of carbon dioxide $\left(\mathrm{CO}_{2}\right)$ from the flue gas stream [2]. A typical oxycombustion process consists of an air separation unit (ASU) that produces nearly pure $\mathrm{O}_{2}(\geq 95 \mathrm{vol} \%)$ to combust coal in an oxy-combustor, with the combusted gas stream exchanging heat with a steam cycle to generate electric power. The oxy-combustion process performance is limited by (a) the efficiency of the ASU, which can impose a significant parasitic load, and (b) the recycling of flue gas required to limit temperatures within the oxy-combustor and maintain the mass flow of the combusted gas steam (especially in systems intended for retrofitting).

Most schemes to limit temperatures within the oxy-combustor involve recirculating a fraction of the $\mathrm{CO}_{2}$-rich flue gas back into the oxy-combustor. If this is done with a gas stream taken before flue gas desulfurization (FGD), then the oxy-combustor must operate with much higher levels of sulphur oxides $\left(\mathrm{SO}_{\mathrm{x}}\right)$, which increase corrosion concerns. This is termed hot-gas-recycle (HGR). If recirculation is done after FGD, then there will be a higher efficiency loss-but $\mathrm{SO}_{x}$ levels will be relatively low and similar to air-combustion. The recirculation path after FGD could go directly back into the oxy-combustor or go through a water removal step to reduce its water content. These recirculation paths are shown schematically in Fig. 1 as recirculation paths A, B, and C. There are three major areas of corrosion concern within the boiler: water wall corrosion, superheater $(\mathrm{SH}) /$ reheater $(\mathrm{RH})$ corrosion, and dew point corrosion. The research presented here targets $\mathrm{SH} / \mathrm{RH}$ conditions.

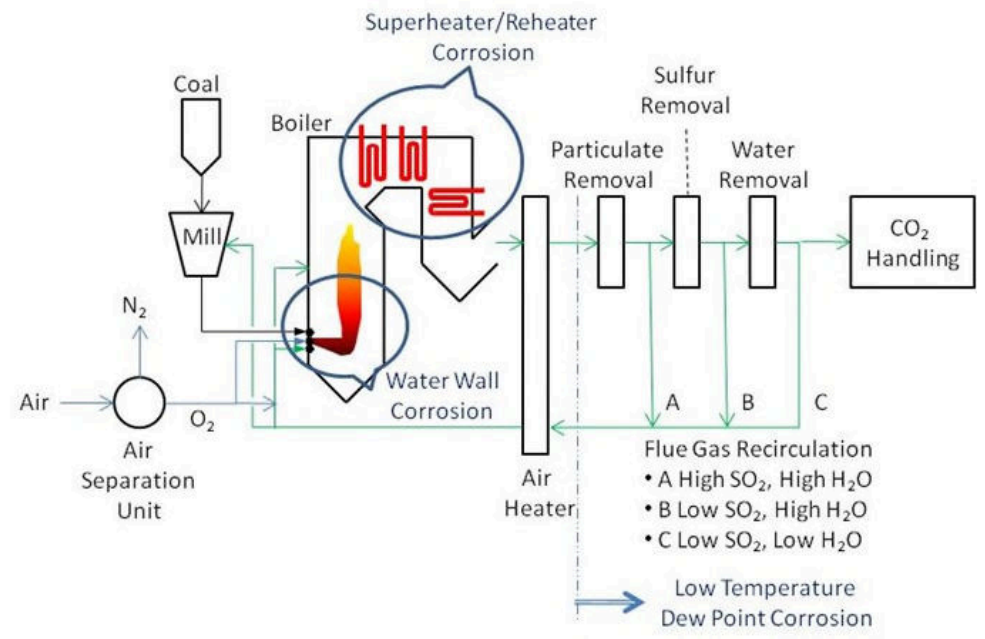

Fig. 1. Schematic of an oxy-combustion coal boiler showing major areas of corrosion concern and three different possible flue gas recirculation paths.

The primary fireside corrosion mechanism of $\mathrm{SH} / \mathrm{RH}$ boiler tubing relies on the formation of liquid sulphates that result from reactions between deposited ash (containing relatively high melting point $\left.(\mathrm{Na}, \mathrm{K})_{2} \mathrm{SO}_{4}\right)$ and $\mathrm{SO}_{x}$ with iron oxides either from the alloy scale or from the deposited ash [3]. The lowest melting point sulphates within these types of deposits are alkali iron trisulphates-although the more general description of a $(\mathrm{Na}, \mathrm{K})_{2} \mathrm{SO}_{4}-\mathrm{Fe}_{2}\left(\mathrm{SO}_{4}\right)_{3}$ solution being the corrosive liquid deposit is likely to 
be more accurate [3]. Rapid corrosion occurs after the molten phase contacts the alloy, either through flaws in the oxide scale or after the oxide scale dissolves ("fluxes") into the molten phase. The fluxing reactions can be either acidic or basic, depending on the local chemistry of the liquid phase and oxide scale [4]. This is analogous to type II hot corrosion of turbine blades, where rapid corrosion occurs after an incubation period and is characterised by an uneven and pitted surface. High $\mathrm{Cr}$ content alloys, up to $22 \mathrm{wt} \%$, are beneficial in reducing fireside boiler corrosion [5].

The reported effects of oxy-combustion on fireside corrosion have been mixed for Fe9Cr ferriticmartensitic steels [5-22]. Hjörnhede et al. [6] examined oxyfuel pilot plant exposures of Fe9Cr steels at Vattenfall and found no significant differences between oxy-fired and air-fired ash deposits, corrosion rates, or carburization. This was not expected as $\mathrm{SO}_{2}$ levels were a factor of four greater for oxycombustion than for air-combustion. Chandra et al. [7] found that 9-12 $\mathrm{Cr}$ ferritic-martensitic steels in oxy-combustion environments $\left(\mathrm{CO}_{2}, 27 \% \mathrm{~N}_{2}, 2 \% \mathrm{O}_{2}, 1 \% \mathrm{SO}_{2}\right)$ were susceptible to carburization. SteinBrzozowska et al. $[8,9]$ found fireside corrosion for $\mathrm{Fe} 9 \mathrm{Cr}$ steels in oxy-combustion environments to increase with increasing $\mathrm{SO}_{2}$ and increasing temperature (to $650^{\circ} \mathrm{C}$ ). Robertson et al [5] found corrosion rates for $\mathrm{T91}$ to be the same, or somewhat higher, in air-combustion than in oxy-combustion (for the same $\mathrm{SO}_{2}$ content). They concluded that conventional materials used in subcritical and supercritical aircombustion boilers would be suitable for oxy-combustion with similar $\mathrm{SO}_{2}$ levels. It should be noted that observing carburization generally requires etching, and not all studies performed this step.

Holcomb et al [10] found for short times $(100 \mathrm{~h})$, with a deposit of $\mathrm{K}_{2} \mathrm{SO}_{4}, \mathrm{Na}_{2} \mathrm{SO}_{4}$, and $\mathrm{Fe}_{2} \mathrm{O}_{3}$ in a 1.5:1.5:1.0 molar ratio, that there was an apparent threshold in $\mathrm{SO}_{3}(\mathrm{~g})$ levels (between $10^{-4}$ and $10^{-3}$ atm), below which corrosion was much reduced. Section loss measured after $240 \mathrm{~h}$ for T91, with a deposit of $40 \% \mathrm{Al}_{2} \mathrm{O}_{3}, 30 \% \mathrm{SiO}_{2}, 30 \% \mathrm{Fe}_{2} \mathrm{O}_{3}, 5 \% \mathrm{Na}_{2} \mathrm{SO}_{4}$ and $5 \% \mathrm{~K}_{2} \mathrm{SO}_{4}$ (mol\%), showed more metal loss for oxy-combustion gases with high $\mathrm{H}_{2} \mathrm{O}$ contents (for both low and high $\mathrm{SO}_{2}$ contents) than for aircombustion or low $\mathrm{H}_{2} \mathrm{O} /$ low $\mathrm{SO}_{2}$ oxy-combustion gases. The present work presented here includes an update of this work, and these longer exposure times will be shown to change the metal loss response with gas composition.

Combining co-firing of fuels and oxy-firing systems is an approach to develop efficient power plants while reducing $\mathrm{CO}_{2}$ emissions [11-14]. Biomass is classed as carbon neutral fuel, and so has zero net $\mathrm{CO}_{2}$ emissions and the use of oxy-firing technologies for fuel combustion facilitates the post-combustion capture of $\mathrm{CO}_{2}$ [15-17]. It is believed that co-firing biomass such as cereal co-product (CCP) with a UK coal will release elevated levels of $\mathrm{Cl}$ and alkali metal $(\mathrm{K})$, with a possible formation of $\mathrm{KCl}[16,18]$ on the heat exchanger surfaces. At present time alkali salts have been in focus extensively as well as chlorineinduced high-temperature corrosion caused by alkali chlorides $[19,20]$. Much attention of the subject is given in the literature [21,22].

Similarly, oxy-firing of such fuel blends will result in elevated levels of $\mathrm{CO}_{2}, \mathrm{H}_{2} \mathrm{O}$ and corrosive gases $(\mathrm{HCl}$ and $\mathrm{SO}_{\mathrm{x}}$ ) [14]. Both approaches (co-firing and oxy-firing) will change the combustion gas chemistry considerably and raise concerns for the life of the SH/RH tubes. Therefore, retrofitting existing power plants into co-firing units or oxy-firing without sufficient experimental data carries substantial risk.

In this paper degradation of T91 $(\sim 9 \% \mathrm{Cr})$ in simulated oxy-firing conditions is presented. Tests conducted at $600{ }^{\circ} \mathrm{C}$ focused on deposit chemistry effects under combined co-firing coal/biomass and oxy-combustion conditions. Tests conducted at $700^{\circ} \mathrm{C}$ focused on gas phase chemistry effects under oxy-combustion conditions. 


\section{Experimental Procedures}

The tests were conducted at 600 and $700{ }^{\circ} \mathrm{C}$, with different heats of T91 used at each temperature. These steels have a metastable tempered martensite structure that is quite persistent at boiler temperatures; ferrite is the stable phase. Exposure temperatures of $700^{\circ} \mathrm{C}$ and above are higher than the ferritic-martensitic steels would see in steam boiler service as a metal temperature. However, actual service conditions are not isothermal and ash and outer oxide layers on the fireside of the boiler tube would be expected to be at higher temperatures than the alloy.

The alloy compositions are given in Table 1 . The composition of the heat used at $600{ }^{\circ} \mathrm{C}$ was measured by energy dispersive $\mathrm{x}$-ray analysis (EDX). The composition of the heat used at $700^{\circ} \mathrm{C}$ was measured by wavelength dispersive $x$-ray fluorescence (WDXRF) with a Rigaku ZSX Primus II. The exceptions were for $\mathrm{C}$ and $\mathrm{N}$, where nominal compositions are listed.

TABLE 1. Alloy compositions, wt \%.

\begin{tabular}{lrrrrrrrrrrrr}
\hline Alloy & $\mathrm{T},{ }^{\circ} \mathrm{C}$ & $\mathrm{Fe}$ & $\mathrm{Cr}$ & $\mathrm{Ni}$ & $\mathrm{Mo}$ & $\mathrm{C}$ & $\mathrm{N}$ & $\mathrm{Si}$ & $\mathrm{Al}$ & $\mathrm{Mn}$ & $\mathrm{V}$ & $\mathrm{Cu}$ \\
\hline $\mathrm{T} 91$ & 600 & Bal & 8.36 & 0.21 & 0.90 & 0.10 & 0.05 & 0.12 & 0.02 & 0.45 & & 0.17 \\
$\mathrm{~T} 91$ & 700 & Bal & 8.48 & 0.16 & 0.99 & 0.10 & 0.05 & 0.35 & & 0.41 & 0.20 & 0.18 \\
\hline
\end{tabular}

Test coupons were machined from commercial tubes. For the $600{ }^{\circ} \mathrm{C}$ tests the coupons were curved tube segments ( $\sim 50^{\circ}$ tube arcs), with dimensions approximately $15 \mathrm{~mm}$ long with a $4 \mathrm{~mm}$ wall thickness. All surfaces were ground to ISO/FEPA 600 grit surface $(25.8 \mu \mathrm{m}$ particle diameter, roughness average $\left(R_{a}\right)$ of $\left.<0.4 \mu \mathrm{m}\right)$. For the $700{ }^{\circ} \mathrm{C}$ tests the coupons were flat, with dimensions approximately $19 \times 13 \times 3$ $\mathrm{mm}$. All surfaces were ground to CAMI 600 grit surface $\left(16.0 \mu \mathrm{m}\right.$ particle diameter, $R_{\mathrm{a}}$ of $\left.0.13 \mu \mathrm{m}\right)$.

\section{$600{ }^{\circ} \mathrm{C}$ Test Procedures (tests focused on deposit effects in coal/biomass co-firing)}

A vertical alumina-lined controlled atmosphere furnace was used for these tests. This system can expose up to 24 samples in alumina crucibles held by an alumina frame. The test was run in a series of five $200 \mathrm{~h}$ segments (to give a total exposure time of 1000 hours) using the well-established "deposit recoat" technique $[18,23]$.

The test exposure conditions were established by a detailed study of the potential gas compositions and deposit compositions/fluxes that could be produced if an oxy-fired system was fired using a common UK coal (Daw Mill) and biomass product (cereal co-product, CCP) for use in UK power stations [16]. The gas composition predicted for the use of $80 \mathrm{wt} \%$ of the UK coal and $20 \%$ of the CCP combined with HGR and $\mathrm{O}_{2}$ (at 95 vol \% purity) were calculated using spreadsheet-based models that have been validated using pilot plant data $[13,16]$. These gas compositions were simplified (to one composition, $59 \% \mathrm{CO}_{2}, 5.2 \% \mathrm{~N}_{2}$, $31 \% \mathrm{H}_{2} \mathrm{O}, 4 \% \mathrm{O}_{2}, 0.626 \% \mathrm{SO}_{2}$ and $0.17 \% \mathrm{HCl}$ ) to include their key active components for corrosion testing in $\mathrm{SH} / \mathrm{RH}$ environments-shown in Table 2, in the Oxy-Combustion "Co-Fired" $600^{\circ} \mathrm{C}$ column. The OxyCombustion "Co-Fired" gas mixture was achieved by combining three pre-mixed gas bottles $\left(\mathrm{HCl}-\mathrm{N}_{2}-\mathrm{CO}_{2}\right.$, $\mathrm{SO}_{2}-\mathrm{CO}_{2}-\mathrm{O}_{2}$, and $\mathrm{CO}_{2}$ ) using mass flow controllers. Deionized water was added with a peristaltic pump. 
TABLE 2. Gas phase compositions, vol \%.

\begin{tabular}{cccccc}
\hline Gas & $\begin{array}{c}\text { Oxy- } \\
\text { Combustion } \\
\text { “Co-Fired" }\end{array}$ & $\begin{array}{c}\text { Air-Combustion } \\
\text { “Air" }\end{array}$ & $\begin{array}{c}\text { Oxy-Combustion } \\
\text { "FGD < } \mathrm{H}_{2} \mathrm{O} \text { " }\end{array}$ & $\begin{array}{c}\text { Oxy-Combustion } \\
\text { “FGD" }\end{array}$ & $\begin{array}{c}\text { Oxy-Combustion } \\
\text { "HGR" }\end{array}$ \\
\hline $\mathrm{T},{ }^{\circ} \mathrm{C}$ & 600 & 700 & 700 & 700 & 700 \\
\hline $\mathrm{CO}_{2}$ & 59.0 & 14 & 80.2 & 69.2 & 68.6 \\
$\mathrm{~N}_{2}$ & 5.2 & 74.2 & 8.0 & 8.0 & 8.0 \\
$\mathrm{H}_{2} \mathrm{O}$ & 31.0 & 9.0 & 9.0 & 20.0 & 20.0 \\
$\mathrm{O}_{2}$ & 4.0 & 2.5 & 2.5 & 2.5 & 2.5 \\
$\mathrm{SO}_{2}$ & 0.626 & 0.3 & 0.3 & 0.3 & 0.9 \\
$\mathrm{HCl}$ & 0.170 & & & & \\
\hline
\end{tabular}

The chemical compositions of the deposits used in this portion of the study are shown in Table 3 (D0D5). Deposit D6 was only used in the $700{ }^{\circ} \mathrm{C}$ tests that were focused on gas composition effects and is described later. At the start of the test these deposits were applied to the convex surfaces of the samples, using a paint brush, to give a coverage of $20 \mathrm{mg} / \mathrm{cm}^{2}$. After each $200 \mathrm{~h}$ cycle, the samples were unloaded from the furnace and weighed: first in their individual crucibles (together with any spalled deposit/oxide) and then without the crucible (and any spall) to enable the calculation of gross and net mass changes (to assist with monitoring the progress of the test). Following these weight measurements, the samples were each recoated with a further $\sim 20 \mathrm{mg} / \mathrm{cm}^{2}$ of deposit before being reloaded into their crucibles and furnace.

TABLE 3. Chemical composition (mol \%) of the deposits used.

\begin{tabular}{|c|c|c|c|c|c|c|c|c|c|c|}
\hline ID & $\mathrm{T},{ }^{\circ} \mathrm{C}$ & Kaolinite $^{a}$ & $\mathrm{Al}_{2} \mathrm{O}_{3}$ & $\mathrm{SiO}_{2}$ & $\mathrm{Fe}_{2} \mathrm{O}_{3}$ & $\mathrm{Na}_{2} \mathrm{SO}_{4}$ & $\mathrm{~K}_{2} \mathrm{SO}_{4}$ & $\mathrm{KCl}$ & $\mathrm{CaO}$ & $\mathrm{CaCO}_{3}$ \\
\hline DO (bare) & 600 & & & & & & & & & \\
\hline D1 & 600 & & & & 25.0 & 37.5 & 37.5 & & & \\
\hline D2 & 600 & 57.0 & & & 28.0 & 10.0 & & & 5.0 & \\
\hline D3 & 600 & 57.0 & & & 28.0 & 5.0 & 5.0 & & 5.0 & \\
\hline D4 & 600 & 53.0 & & & 27.0 & 5.0 & & 10.0 & 5.0 & \\
\hline D5 & 600 & 57.0 & & & 28.0 & 10.0 & & & & 5.0 \\
\hline D6 & 700 & & 40.0 & 30.0 & 30.0 & 5.0 & 5.0 & & & \\
\hline
\end{tabular}

${ }^{\mathrm{a}} \mathrm{Al}_{2} \mathrm{O}_{3} \cdot 2 \mathrm{SiO}_{2} \cdot 2 \mathrm{H}_{2} \mathrm{O}$

The deposits can be characterised as [24]:

- D0: no deposit (as a reference)

- D1: a deposit composition that is widely used in screening tests. At test conditions it generates an aggressive alkali-iron trisulphate that has been frequently associated with fireside corrosion of $\mathrm{SH} / \mathrm{RH}$ in coal-fired power stations $[13,17,25]$. This deposit causes accelerated fireside corrosion damage.

- D2: a simplified alkali-iron trisulphate composition (without $\mathrm{K}$ ) diluted with kaolinite $\left(\mathrm{Al}_{2} \mathrm{O}_{3} \cdot 2 \mathrm{SiO}_{2} \cdot 2 \mathrm{H}_{2} \mathrm{O}\right), \mathrm{Fe}_{2} \mathrm{O}_{3}$ and $\mathrm{CaO}$ to represent the minerals often found in coals.

- D3: similar to D2, but with $5 \%$ of the $\mathrm{Na}_{2} \mathrm{SO}_{4}$ replaced with $\mathrm{K}_{2} \mathrm{SO}_{4}$.

- D4: similar to D3, but with the $\mathrm{K}$ present as $\mathrm{KCl}$ to investigate one potential effect of biomass cofiring.

- D5: similar to D2, but with $\mathrm{CaO}$ replaced by $\mathrm{CaCO}_{3}$. 
The presence of $\mathrm{CaO}$ in $\mathrm{D} 2-\mathrm{D} 4$ and $\mathrm{CaCO}_{3}$ in $\mathrm{D} 5$ can lead to the formation of alkali calcium tri-sulphates instead of alkali iron tri-sulphates and are generally less corrosive [24, 26].

Following their exposure, samples were carefully mounted using jigs and a low shrinkage epoxy resin $50 \%$ filled with ballotini (to further reduce shrinkage). These mounted samples were then sectioned (using a CBN cutting wheel and oil-based lubricant) perpendicular to their lengths. The cross-sections were prepared using standard $\mathrm{SiC}$ grinding papers and then diamond pastes using oil-based lubricants.

After preparation the cross-sections were measured using a calibrated $x$-y stage on a Leitz optical microscope linked to an image analyser system to generate accurate measurements of the edge of the remaining metal and the depth of any internal damage. These measurements were compared to the pre-exposure sample dimensions (collected using a digital micrometre, with a resolution of $1 \mu \mathrm{m}$ ) to produce distributions of the changes in metal thickness (with and without any internal damage) that had been caused by the exposures. Detailed descriptions of this procedure for dimensional metrology was reported previously [e.g. 24].

The microstructure of the deposits and corrosion products were characterised using an FEI environmental scanning electron microscope (ESEM) with Oxford Instruments energy dispersive X-ray analysis (EDX).

Additional details of the procedures used for the $600{ }^{\circ} \mathrm{C}$ exposures can be found in references [23, 24 and 27].

\section{$700{ }^{\circ} \mathrm{C}$ Test Procedures (tests focused on gas composition effects in air- and oxy-firing)}

The tests were conducted in horizontal tube furnaces, with the samples placed face down in alumina boats. Synthetic ash was used to cover the samples. The components of the ash were ball-milled for good mixing. The specimens were buried with a $3 \mathrm{~mm}$ cover of ash, which was then lightly compacted using a mass equivalent to $40 \mathrm{~g} / \mathrm{cm}^{2}$. The composition of the ash used at $700{ }^{\circ} \mathrm{C}$ (D6) is given in Table 3 . Compared to the other deposits, $\mathrm{D} 6$ used $\mathrm{Al}_{2} \mathrm{O}_{3}$ and $\mathrm{SiO}_{2}$ instead of Kaolinite for the (expected) inert portion of the ash. Deposit D6 is similar to D1 in that it doesn't contain $\mathrm{KCl}, \mathrm{CaO}$ or $\mathrm{CaCO}_{3}$, but it has a much smaller amount of sulphates. It should be less of an accelerated test than the use of D1.

The specimens were exposed for either $240 \mathrm{~h}$ (ash-retained exposures), or for $1440 \mathrm{~h}$ in $240 \mathrm{~h}$ test segments (section loss exposures) in the four gas mixtures associated with either air-combustion or oxycombustion gas mixtures as shown in Table 2. The shorthand for the four cases are "air" for aircombustion, "FGD $<\mathrm{H} 2 \mathrm{O}$ " for oxy-combustion after flue gas desulfurization (FGD) and water removal in the flue gas recirculation stream, "FGD" after desulfurization in the flue gas recirculation stream, and "HGR" for the hot-gas-recycle case (no purification of the recirculation stream). The four gas mixtures were achieved by combining pure gases using mass flow controllers. Deionized water was added with a syringe pump. The gas mixtures flowed at a rate of $25 \mathrm{~cm} / \mathrm{min}$ (at $700{ }^{\circ} \mathrm{C}$ ) first past a Pt/Rh mesh and then over the boat with samples and ash. The $\mathrm{Pt} / \mathrm{Rh}$ mesh was to catalyse $\mathrm{SO}_{3}$ formation from $\mathrm{SO}_{2}$ and $\mathrm{O}_{2}$. Oxides in the ash, whether in laboratory ash or in a boiler, also catalyse the formation of $\mathrm{SO}_{3}$. 


\section{Ash-Retained Exposures}

After the test the entire alumina boat (with samples and intact ash) was embedded in epoxy and crosssections were cut and examined. This allowed observation of the alloy-scale-ash largely intact after exposure. The sectioning step used water for lubricant and cooling, so water soluble species containing $\mathrm{Na}$ and $\mathrm{K}$ may have been lost. Examinations were by polarized light $(\mathrm{PL})$ and differential interference contrast (DIC) with a Leitz metallurgical microscope. Additional examinations were done using fieldemission scanning electron microscopy (SEM) with both a JEOL 7000F equipped with Oxford energy dispersive x-ray (EDX) and wavelength dispersive spectrometer (WDS) detectors and a FEI Quanta 600 equipped with an Oxford X-Max 80 EDX.

\section{Section Loss Exposures}

Exposures were done in $240 \mathrm{~h}$ increments on triplicate samples. After each exposure, the ash was removed, and the samples gently cleaned in isopropyl alcohol. Mass changes measurements were made, but since significant ash remained on the surface, these measurements were of minimal value. Light microscopy macro images were made of each sample. One of each triplicate or duplicate sample was cut for cross-section analysis after 240 and $480 \mathrm{~h}$. All the samples (the enact sample(s) and remaining portion of the cut sample) of each alloy were exposed to the next $240 \mathrm{~h}$ exposure. Care was taken to ensure that the same side was facing upwards on both exposures. After the final exposure period, all the samples were cross-sectioned for analysis. Section loss measurements were made by comparing pre-test thickness measurements from 15 separate locations on the sample with image analysis done on high-contrast light microscopy images of cross-sections after the test. The image analysis consisted of measuring the metal thickness at many regularly spaced locations (typically 50 locations) along the width of the sample. Measurements near the edges of the cross-section were not included in the analysis. Similar section loss measurements were also made for alloys in the $24 \mathrm{~h}$ ashretained exposures.

\section{Results and Discussion}

\section{$600{ }^{\circ} \mathrm{C}$ Tests (tests focused on deposit effects in coal/biomass co-firing)}

Figure 2 shows the time dependence of the mass change data for the different deposits. After 1000 hours exposure these data ranked the mass gains for the T91 samples with different deposits (from lowest to highest) as D0, D2, D3, D5, D4 and D1. As expected, the sample without deposit (D0) had the lowest mass change, and the most aggressive deposit (D1) produced the highest mass change. However, more detailed interpretation of such data is limited by deposit/corrosion product spallation.

Dimensional metrology needs to be used to obtain a better dataset for the metal damage generated by fireside corrosion. The pre- and post-exposure dimensional metrology processes are used to produce datasets of changes in metal thickness as a function of position around the samples. These datasets were then converted into metal losses and corrected for calibration differences between the pre- and post-exposure metrology processes (using data from reference samples), before being reordered into distributions of metal loss (from least to greatest). These processed data were plotted in Figure 3 as metal loss (with units of $\mu \mathrm{m}$ ) as a function of cumulative normal probability (with units of standard deviations). 


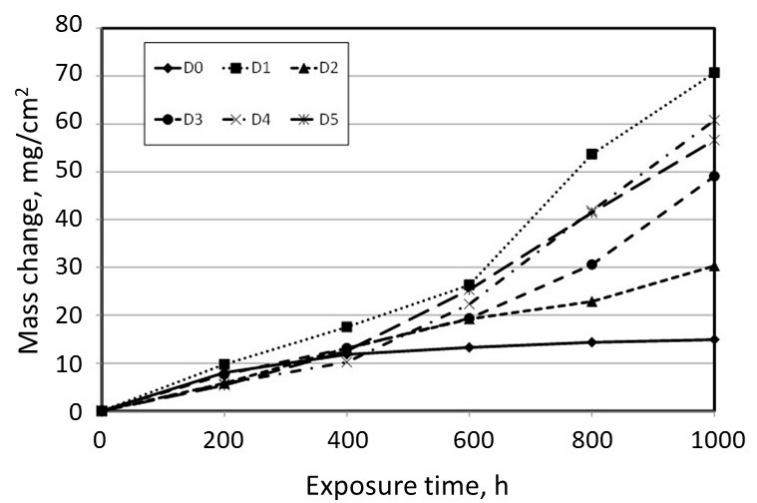

Fig. 2. Mass change data of T91 with different deposits after exposure at $600{ }^{\circ} \mathrm{C}$ for $1000 \mathrm{~h}$ (D0 bare, D1 high $\mathrm{SO}_{4}, \mathrm{D} 2-\mathrm{D} 5$ with $\mathrm{Ca}$, D4 with $\mathrm{KCl}$ ).

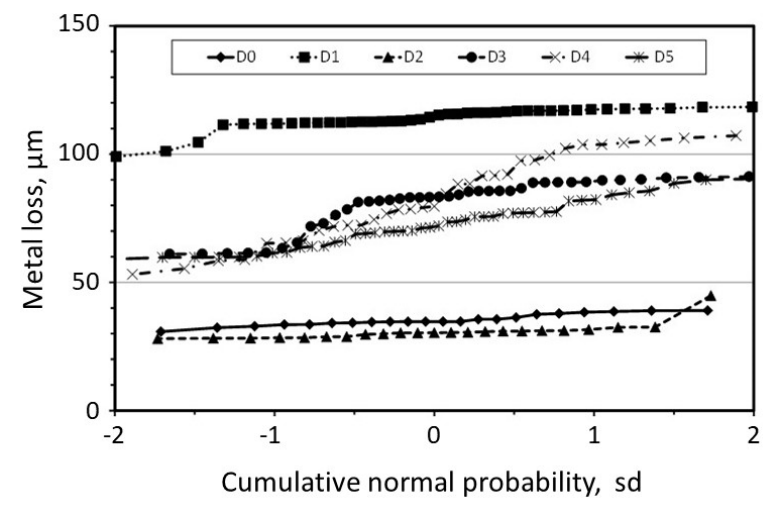

Fig. 3. Dimensional metrology of T91 with different deposits after exposure at $600{ }^{\circ} \mathrm{C}$ for $1000 \mathrm{~h}$ (D0 bare, D1 high $\mathrm{SO}_{4}, \mathrm{D} 2-\mathrm{D} 5$ with $\mathrm{Ca}, \mathrm{D} 4$ with $\mathrm{KCl})$.

These data show that the lowest metal losses were obtained from samples with no deposit (D0) and with deposit D2; with the samples still being in the incubation stage of fireside corrosion. The highest metal losses were obtained with deposit D1 (which had been anticipated to be the most aggressive deposit); with the sample having been in the propagation stage of fireside corrosion for most of its exposure. Intermediate metal losses were obtained for deposits D3-D5; with samples having transitioned from incubation to propagation damage during the course of their exposures.

ESEM/EDX analyses were performed after $1000 \mathrm{~h}$ of exposure of samples exposed with deposit D1 and without deposit (DO); backscattered ESEM images are shown in Fig. 4. Without a deposit (DO), the scale was $\sim 90 \mu \mathrm{m}$ thick and had an outer layer of $\mathrm{Fe}_{3} \mathrm{O}_{4}$ (with some $\mathrm{Cr}$ ) and an inner layer of Fe-Cr spinel (with some S). In contrast, with deposit D1 the scale was much thicker ( 300-340 $\mu \mathrm{m})$, with a surface deposit/corrosion product mix of $\sim 300 \mu \mathrm{m}$. The inner oxide layer was an Fe-Cr spinel with $\mathrm{S}$ near the alloy and $\mathrm{Fe}_{3} \mathrm{O}_{4}$ with $\mathrm{Cr}, \mathrm{S}, \mathrm{Na}$, and $\mathrm{K}$ below a surface deposit/corrosion product mix.

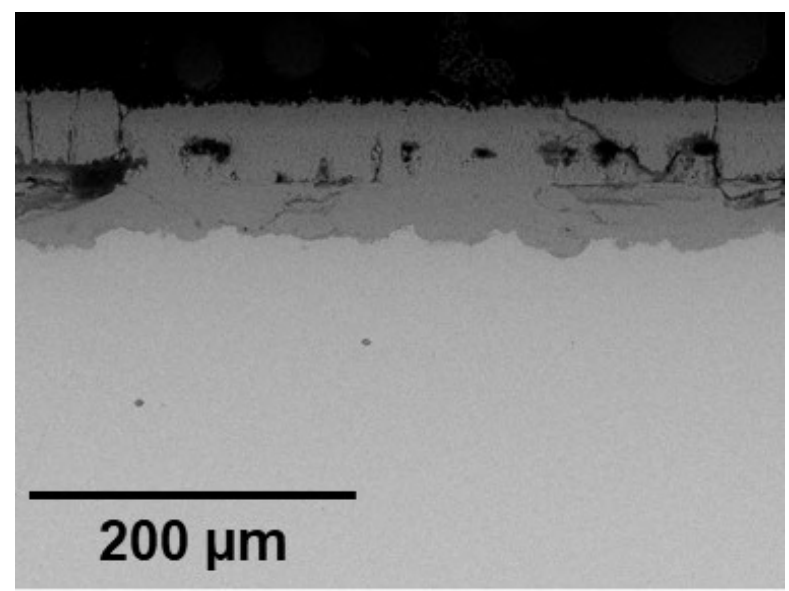

a)

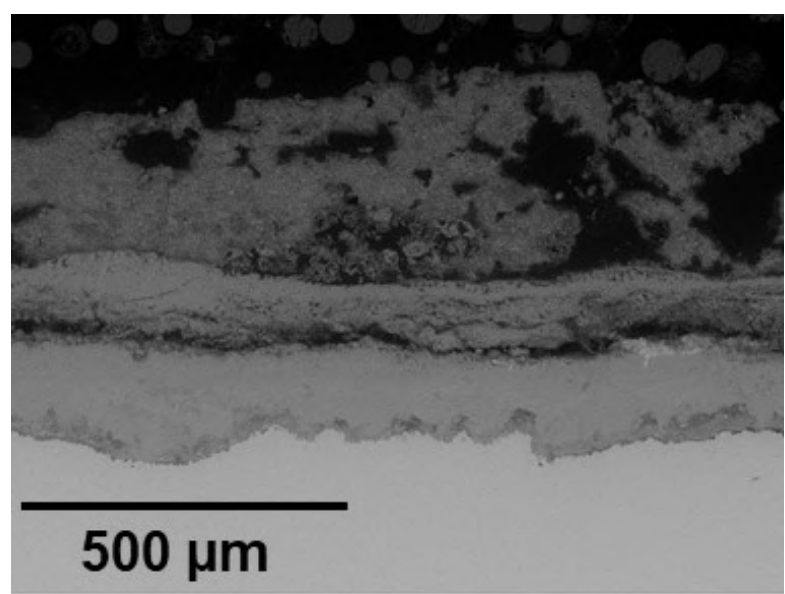

b)

Fig. 4. Back-scattered electron images of T91 exposed in simulated oxy-fired combustion gases at $600{ }^{\circ} \mathrm{C}$ for $1000 \mathrm{~h}$; a) without any deposit (D0), b) with the deposit with high levels of $\mathrm{SO}_{4}(\mathrm{D} 1)$. 
Based on the research reported elsewhere [e.g. 24,25,28], it is suggested that the compounds applied in deposit D1 have reacted with each other and the gaseous environment to form alkali-iron sulphates that have melted below the exposure temperature for this test and enabled the propagation of fireside corrosion to start quickly. In contrast, the initial deposit D2, with the addition of an alumina-silicate mineral and $\mathrm{CaO}$ as well as the removal of $\mathrm{K}_{2} \mathrm{SO}_{4}$, resulted in a surface condition that did not cause fireside corrosion during this exposure (due to its melting point being higher than the exposure temperature). Deposits $\mathrm{D} 3-\mathrm{D} 5$, with varying initial levels $\mathrm{Na}_{2} \mathrm{SO}_{4}, \mathrm{~K}_{2} \mathrm{SO}_{4}, \mathrm{KCl}, \mathrm{CaO}$ and $\mathrm{CaCO}_{3}$, resulted in surface conditions that enabled the transition between the incubation and propagation stages of hot corrosion to occur during these exposures. This was due to reactions between the complex initial deposits and gaseous environments generating mixtures with melting points that have moved below the test temperature, enabling the fireside corrosion fluxing reactions to start.

\section{$700{ }^{\circ} \mathrm{C}$ Tests (tests focused on gas composition effects in air- and oxy-firing)}

\section{Ash-Retained Exposures}

Significant corrosion was observed after exposure. Fig. 5 shows T91 with retained ash after $240 \mathrm{~h}$ exposure in an oxy-combustion "FGD" gas $\left(\mathrm{CO}_{2}+8 \% \mathrm{~N}_{2}+20 \% \mathrm{H}_{2} \mathrm{O}+2.5 \% \mathrm{O}_{2}+0.3 \% \mathrm{SO}_{2}\right)$ with a $\mathrm{D} 6$ ash cover. The oxide scale consists of an inner scale containing ( $\mathrm{Fe}, \mathrm{Cr}$ ) oxide and an outer scale consisting of Fe oxide. This is typical of $9 \mathrm{Cr}$ steel oxidation. Sulphur was found within the inner $(\mathrm{Fe}, \mathrm{Cr})$ oxide scale. Above the outer oxide scale is an oxide deposition zone, where dissolved oxide, from a fluxing reaction, has deposited within the ash cover. Above the oxide deposition zone is an ash affected zone, which by $\mathrm{PL}$ has a different coloration than the remainder of the ash cover. Examination of the ash affected zone at higher magnification, Fig. 5d, shows needle-shaped Fe oxides growing within the pores in the ash. These needles are not present further away from the alloy. The needles appear to be the location of a reaction front where iron oxides precipitate, in a non-protective morphology, after being dissolved at the scale-ash interface. This is consistent with a fluxing-type model of hot corrosion [4]. 


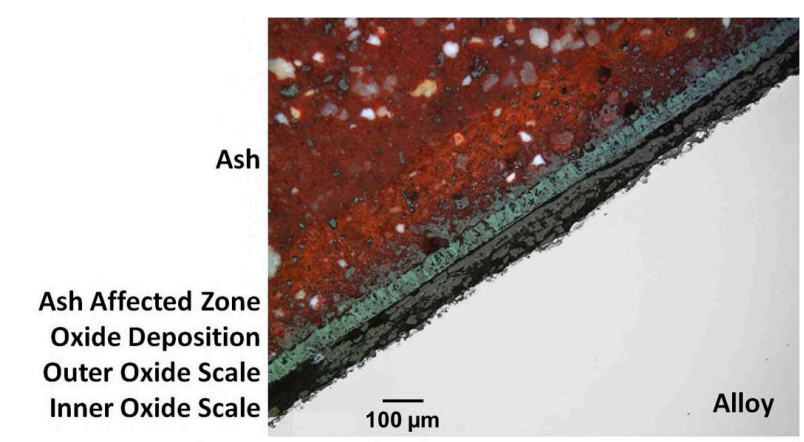

a)
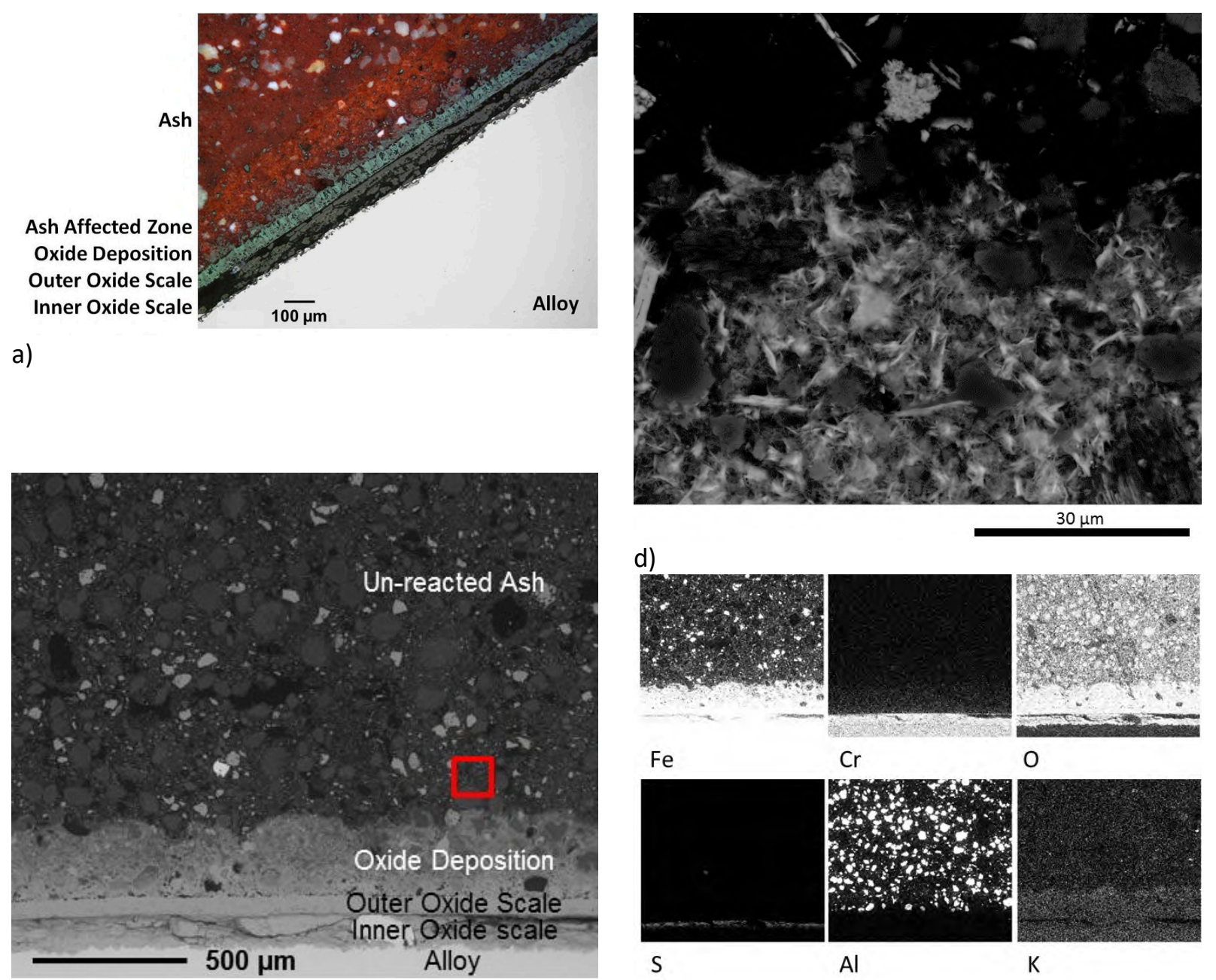

d)

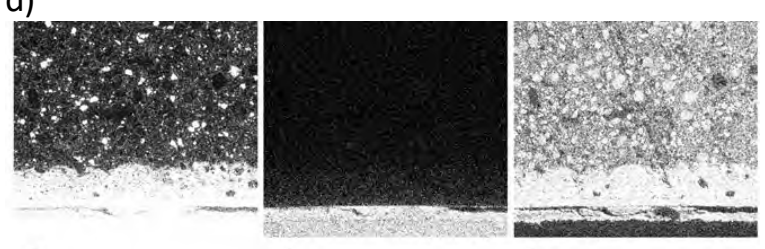

Fe

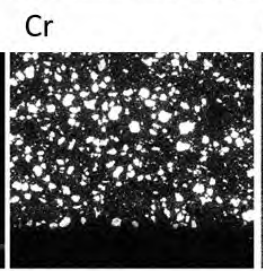

O

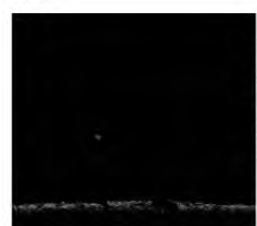

$\mathrm{S}$

Al

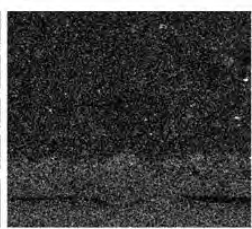

K

c)

b)

Fig. 5. T91 with retained ash after $240 \mathrm{~h}$ exposure in an oxy-combustion " $\mathrm{FGD}$ " gas $\left(\mathrm{CO}_{2}+8 \% \mathrm{~N}_{2}+20 \%\right.$ $\mathrm{H}_{2} \mathrm{O}+2.5 \% \mathrm{O}_{2}+0.3 \% \mathrm{SO}_{2}$ ) at $700{ }^{\circ} \mathrm{C}$ with a D6 ash cover: a) polarized light (PL) microscopy, b) SEM image, $c$ ) elemental maps from the area in $b$, and d) higher magnification red-box area in $b$ of needleshaped iron oxide grown within the ash pores.

Figure 6 shows edge effects for T91 after exposure for $240 \mathrm{~h}$ at $700{ }^{\circ} \mathrm{C}$ with an $\mathrm{D} 6$ ash and an oxycombustion $\mathrm{FGD}<\mathrm{H}_{2} \mathrm{O}$ gas $\left(\mathrm{CO}_{2}+8 \% \mathrm{~N}_{2}+9 \% \mathrm{H}_{2} \mathrm{O}+2.5 \% \mathrm{O}_{2}+0.3 \% \mathrm{SO}_{2}\right)$. The oxide deposition region is much thicker near the edges of the sample. There is visible section loss on the right-hand edge of the sample. However, the inner and outer oxide scales have similar thicknesses, regardless of distance from an edge. 


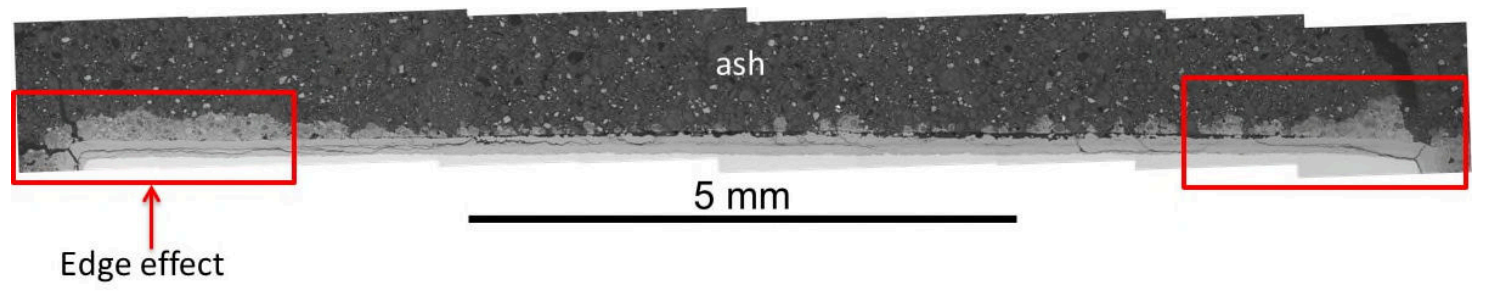

Fig. 6. Stitched-together back-scattered electron images of T91 after exposure for $240 \mathrm{~h}$ at $700{ }^{\circ} \mathrm{C}$ with D6 ash and an oxy-combustion FGD $<\mathrm{H}_{2} \mathrm{O}$ gas $\left(\mathrm{CO}_{2}+8 \% \mathrm{~N}_{2}+9 \% \mathrm{H}_{2} \mathrm{O}+2.5 \% \mathrm{O}_{2}+0.3 \% \mathrm{SO}_{2}\right)$.

\section{Section Loss Exposures}

An example of the remaining thickness measurements taken on cross-sections after a test is in Fig. 7a for T91 after $1440 \mathrm{~h}$ at $700{ }^{\circ} \mathrm{C}$ in the oxy-combustion HGR gas with D6 ash. Each measurement was taken at regular intervals, approximately $250 \mu \mathrm{m}$ apart from each other. Normally five images for each specimen, covering the entire cross-section, are used, generating about 50 measurements per specimen. The difference between these measurements and the initial thickness are used to determine metal loss. Metal loss data were arranged from smallest to largest and put into cumulative probability plots. Figure $7 \mathrm{~b}$ shows a cumulative probability plot for the entire T91 sample shown in Fig. 7a. There is good agreement with a normal distribution, which is associated with general corrosion. The cumulative normal distribution is determined from the mean and variance of the metal loss data, using the Excel Normdist function-it is not a fit of the individual data points.
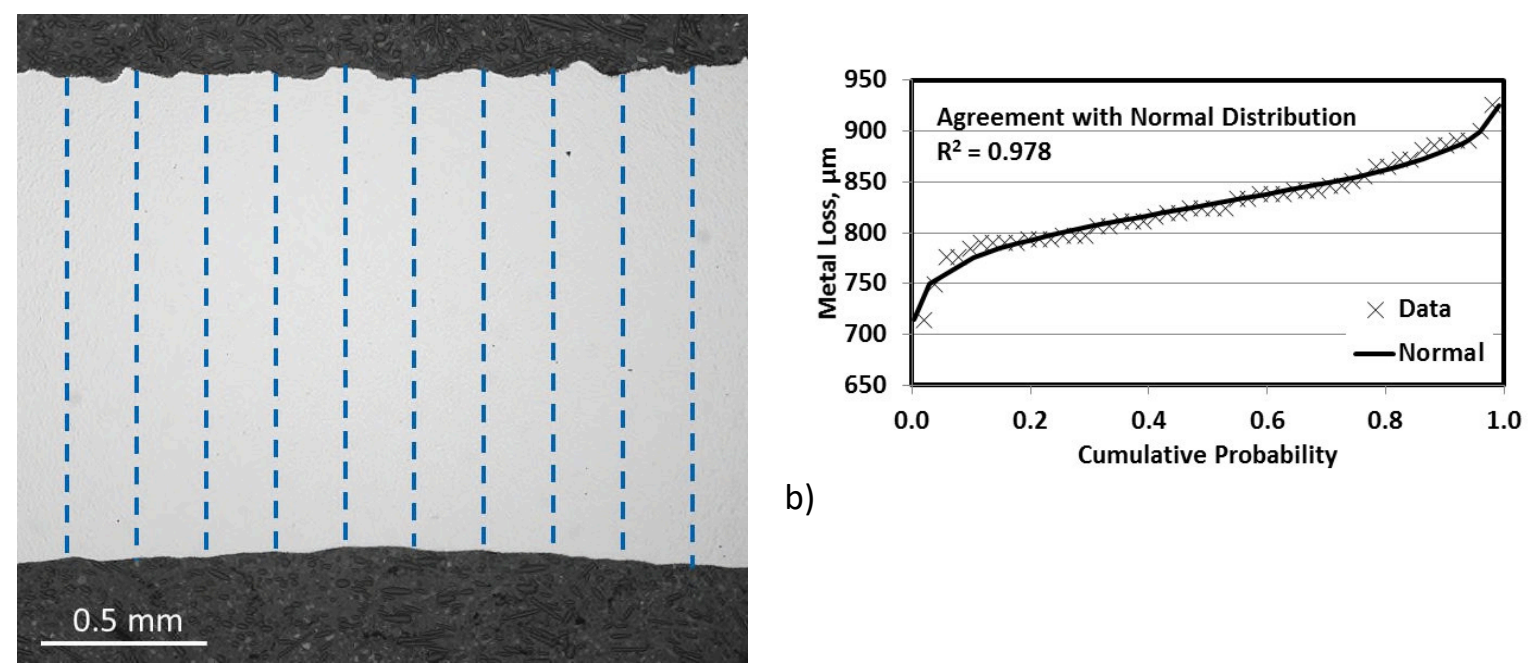

b)

a)

Fig. 7. a) Remaining thickness measurement locations for T91 after $1440 \mathrm{~h}$ at $700{ }^{\circ} \mathrm{C}$ in the oxycombustion HGR gas with D6 ash, and b) cumulative probability plot for the entire T91 sample.

Even though corrosion coupons were placed in the alumina boat, and covered with ash on one side, corrosion damage was typically observed on both sides of the sample.

Figure 8 shows the mean metal section loss for T91 after exposure under a D6 ash and with four different gas compositions. Several observations can be made. First, there was little difference in mean metal section loss $(720-820 \mu \mathrm{m})$ after $1440 \mathrm{~h}$ of exposure. Second, the initial differences after $240 \mathrm{~h}$, 
noted in an earlier publication [10], are no longer apparent after longer exposures. Finally, the overall section loss kinetics appeared linear, and the total section losses substantial.

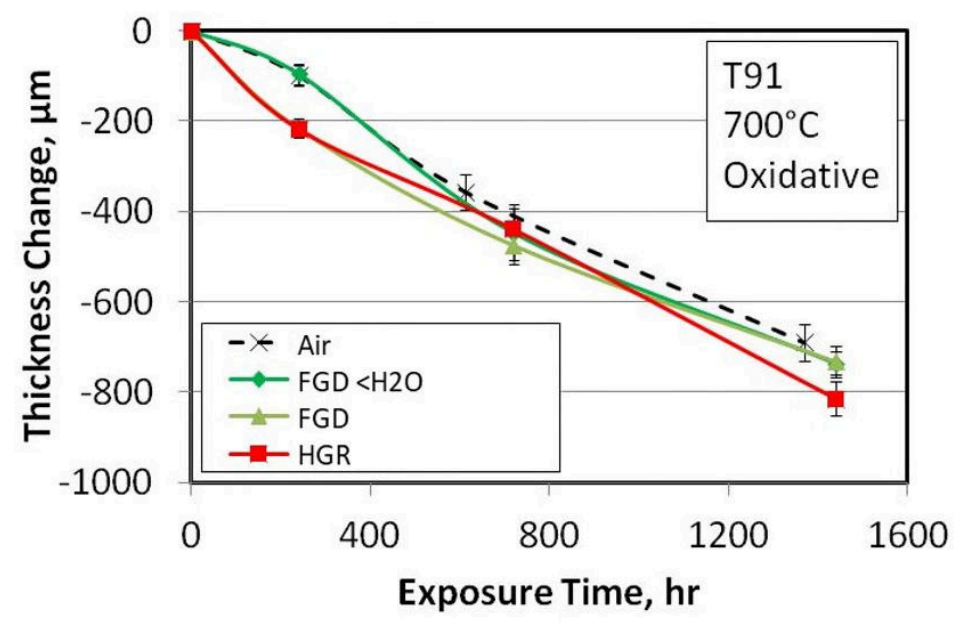

Fig. 8. Mean alloy section loss for T91 exposed in four different combustion gases under D6 ash.

In similar tests (alloy T92 in with deposit D1 for $1000 \mathrm{~h}$ ) Hussain [29] showed metal loss differences at $700{ }^{\circ} \mathrm{C}$ of $\sim 1100 \mu \mathrm{m}$ for a HGR case and $\sim 850 \mu \mathrm{m}$ for an air-fired case. The major differences in test procedures were the much higher $\mathrm{SO}_{4}$ levels in the Hussain result, but with the use of much thinner deposits $\left(20 \mathrm{mg} / \mathrm{cm}^{2}\right.$ as opposed to $3 \mathrm{~mm}$ of ash cover). The section loss results in Fig. 8 could be a consequence of thicker ash cover masking some of the gas composition differences.

\section{Conclusions}

This paper reported the collaborative results on examining the corrosion resistance of T91 in a variety of oxy-fuel combustion environments. Tests conducted at $600^{\circ} \mathrm{C}$ focused on deposit chemistry effects under combined co-firing coal/biomass and oxy-combustion conditions. Tests conducted at $700{ }^{\circ} \mathrm{C}$ focused on gas phase chemistry effects under oxy-combustion conditions.

The exposures at $600{ }^{\circ} \mathrm{C}$ (tests focused on deposit effects in coal/biomass co-firing) showed:

- $\quad$ Substantial metal losses $(30-120 \mu \mathrm{m})$ were observed for all $1000 \mathrm{~h}$ exposures.

- Under deposit D1 the formation alkali iron sulphates enabled a relatively high rate of metal loss (the highest of the five deposits used at $600^{\circ} \mathrm{C}$ ).

- $\quad$ Lower corrosion damage was observed with deposits D3-D5, which appeared to have delayed the transition to the propagation stage of fireside corrosion.

- Under deposit D2, the metal losses were similar to those observed with no deposit, with the sample still being in the incubation stage of fireside corrosion

The exposures at $700{ }^{\circ} \mathrm{C}$ (tests focused on gas composition effects in air- and oxy-firing) showed:

- $\quad$ Substantial metal losses (720-820 $\mu \mathrm{m})$ were observed for all $1440 \mathrm{~h}$ exposures.

- The oxidation kinetics were linear. 
- Iron oxide morphology, within the ash at the oxide scale-ash interface, was consistent with a fluxing (dissolving and later non-protective precipitation) mechanism.

\section{Acknowlegements}

Parts of this work were performed in support of the US Department of Energy's Fossil Energy Crosscutting Technology Research Program, the UK-US collaboration on Fossil Energy R\&D - Advanced Materials and the UK Research Councils Energy Programme. These include: research executed through NETL Research and Innovation Center's Advanced Alloy Development Field Work Proposal and research performed by AECOM Staff under the RES contract DE-FE-0004000. Other parts of this work were performed by Cranfield University as part of the Supergen Plant Life Extension Consortium (grant

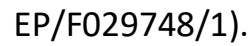

\section{Disclaimer}

Portions of this report were prepared as an account of work sponsored by an agency of the United States Government. Neither the United States Government nor any agency thereof, nor any of their employees, makes any warranty, express or implied, or assumes any legal liability or responsibility for the accuracy, completeness, or usefulness of any information, apparatus, product, or process disclosed, or represents that its use would not infringe privately owned rights. Reference herein to any specific commercial product, process, or service by trade name, trademark, manufacturer, or otherwise does not necessarily constitute or imply its endorsement, recommendation, or favoring by the United States Government or any agency thereof. The views and opinions of authors expressed herein do not necessarily state or reflect those of the United States Government or any agency thereof.

\section{References}

1. United States - United Kingdom collaboration on fossil energy research and development [Internet]. Washington, DC: US Department of Energy; [cited 2018 Feb 15]. Available from https://fossil.energy.gov/usuk/

2. Advanced and innovative power cycles. EPRI Report 3002003664. Palo Alto, CA: EPRI; 2014.

3. Lutz BS, Holcomb GR, Meier GH. Determination of the initiation and propagation mechanism of fireside corrosion. Oxid Met. 2015;84(3-4):353-381.

4. Rapp RA. Hot corrosion of materials: a fluxing mechanism? Corros Sci. 2002;44(2):209-221.

5. Robertson A, Agarwal H, Gagliano M, et al. Oxy-combustion boiler material development. In: Sakkestad BA, editor. Proceedings of the 37th international technical conference on clean coal \& fuel systems; 2012 Jun 3-7; Clearwater, FL. Gaithersburg, MD: Coal Technologies Associates; 2012. p 494-505.

6. Hjörnhede A, Montgomery M, Bjurman M, et al. Preliminary experiences with materials testing at the oxyfuel pilot plant at Schwarzepumpe. In: Lecomte-Beckers J, Contrepois Q, Beck T, et al., editors. Materials for advanced power engineering. Proceedings of the $9^{\text {th }}$ Liège conference on materials for advanced power engineering: 2010 Sep 27-29; Liège, Belgium. Jülich, Germany: Forschungszentrum Jülich; 2010. p. 1244-1259.

7. Chandra K, Kranzmann A, Saliwan Newmann R, et al. High temperature oxidation behavior of 9$12 \% \mathrm{Cr}$ ferritic/martensitic steels in simulated dry oxyfuel environment. Oxid Met. 2015;83(34):291-316.

8. Stein-Brzozowska G, Norling R, Viklund $P$, et al. Fireside corrosion during oxyfuel combustion considering various $\mathrm{SO}_{2}$ contents," Energy Procedia. 2014;51:135-147. 
9. Stein-Brzozowska G, Flórez DM, Maier J, et al. Nickel-base superalloys for ultra-supercritical coal-fired power plants: fireside corrosion. laboratory studies and power plant exposures. Fuel. 2013;108:521-533.

10. Holcomb GR, Tylczak J, Meier GH, et al. Fireside corrosion in oxy-fuel combustion of coal. Oxid Met. 2013;80(5-6):599-610.

11. Dechamps P. The EU research strategy towards zero emission fossil fuel power plants. In: Lecomte-Beckers J, Carton M, Schubert F, et al., editors. Materials for advanced power engineering. Proceedings of the $8^{\text {th }}$ Liège conference on materials for advanced power engineering: 2006 Sep 18-20; Liège, Belgium. Jülich, Germany: Forschungszentrum Jülich; 2006. p. 25-40.

12. Farley M. Clean coal technologies for power generation. In: Strang A, Banks WM, McColvin GM, et al., editors. Power generation in an era of climate change. Proceedings of Parsons: $2007 \mathrm{Sep}$ 11-13; Glasgow, UK. London, UK: IOM: 2007. p. 335-342.

13. Simms NJ, Kilgallon PJ, Oakey JE. Fireside issues in advanced power generation systems. Energy Mater. 2007;2(3):154-160.

14. Bordenet B, Kluger $F$. Thermodynamic modelling of the corrosive deposits in oxy-fuel fired boiler. Mater Sci Forum. 2008;595-598:261-269.

15. Oakey JE, Pinder LW, Vanstone R, et al. Review of status of advanced materials for power generation. Report No. COAL R224, DTI/Pub URN 02/1509. London, UK: Department of Trade and Industry; 2003.

16. Simms NJ, Kilgallon PJ, Oakey JE. Degradation of heat exchanger materials under biomass cofiring conditions. Mater High Temp. 2007;24(4):333-342.

17. Stringer J, Wright IG. Current limitations of high-temperature alloys in practical applications, Oxid Met. 1995;44(1-2):265-308.

18. Skrifvars BJ, Backmana R, Hupaa M, et al. Corrosion of superheater steel materials under alkali salt deposits part 1: the effect of salt deposit composition and temperature. Corros Sci. 2008;50(5):1274-1282.

19. Alexander PA. Laboratory studies of the effects of sulfates and chlorides on the oxidation of superheater alloys. In: Johnson R, Littler DJ, editors. The mechanisms of corrosion by fuel impurities. Proceedings of the international conference held at the Marchwood engineering laboratories: 1963 May 20-24; Marchwood, UK. London, UK: Butterworths, 1963. P. 571-582.

20. Grabke HJ. Fundamental mechanisms of the attack of chlorine, $\mathrm{HCl}$ and chlorides on steel and high temperature alloys in the temperature range $400-900^{\circ} \mathrm{C}$. In: Bryers RW, editor. Incinerating municipal and industrial waste. New York, NY: Hemisphere Publishing Corporation; 1989. p. 161.

21. Petterson J, Petterson C, Asteman H, et al. A pilot-plant study of the effect of alkali salts on the initial stages of the high temperature corrosion of alloy 304L. Mater Sci Forum. 2004;461464:965-972.

22. Nielsen HP, Frandsen F, Dam-Johansen K, et al. The implications of chlorine-associated corrosion on the operation of biomass-fired boilers. Prog Energy Combust Sci. 2000;26(3):283-298.

23. Hussain T, Dudziak T, Simms NJ, et al. Fireside corrosion behaviour of HVOF and plasma sprayed coatings in advanced coal/biomass co-fired power plants. J Therm Spray Technol. 2012;22(5):797-807.

24. Syed AU, Simms NJ, Oakey JE. Fireside corrosion of super-heaters: effects of air and oxy-firing of coal and biomass. Fuel. 2012;101:62-73.

25. Natesan K, Purohit A, Rink DL. Coal-ash corrosion of alloys for combustion power plants. In: Proceedings of the $17^{\text {th }}$ annual conference on fossil energy materials: 2003 Apr 22-24; Baltimore Maryland. Pittsburgh, PA: National Energy Technology Laboratory; 2003. 
26. Karlsson A, Möller PJ, Johansen V. Iron and steel corrosion in a system of $\mathrm{O}_{2}, \mathrm{SO}_{2}$ and alkali chloride. The formation of low melting point salt mixtures. Corros Sci. 1990;30:153-158.

27. Dudziak T, Hussain T, Simms NJ, et al. Fireside corrosion degradation of ferritic alloys at $600{ }^{\circ} \mathrm{C}$ in oxy-fired conditions. Corros Sci. 2014;79:184-191.

28. Paul L, Clark G. Coal ash corrosion resistance of new chromium and chromium silicon alloys. In: Proceedings of corrosion/2005: 2005 Apr 3-7; Houston, TX. Houston, TX: NACE International; 2005. Paper no. 05453.

29. Hussain T, Syed AU, Simms NJ. Trends in fireside corrosion damage to superheaters in air and oxy-firing of coal/biomass. Fuel. 2013;113:787-797. 